\title{
'LIKE GREEN HERB': JULIAN'S UNDERSTANDING OF PURITY AND HIS ATTITUDE TOWARDS JUDAISM IN HIS CONTRA GALILAEOS
}

\author{
Giorgio Scrofani, Scuola Normale Superiore di Pisa (g.scrofani@sns.it)
}

\begin{abstract}
Among the charges levelled against the Christians in Julian's 'Against the Galileans' Judaism and its purity legislation play an essential role: By refusing Jewish sacrificial practice and dietary regulations, Julian argues, the Galileans abandoned the pure and priestly life prescribed by Moses to follow a new path of impurity and moral disorder. Julian aims to prove his allegations by strategically developing a close parallelism between Jews and Hellenes. Against a widespread view, therefore, Judaism plays essentially a polemical role in Julian's reasoning. Only when we consider the continuing attraction which Judaism held for Christians, especially in Antioch, we can properly understand Julian's polemics. Favouring the Jews and supporting the literal interpretation of Scripture on the one hand he affirmed indirectly the Hellenic pure way of life, on the other hand he tried to nourish inner-Christian conflicts.
\end{abstract}

After the death of Constantius II in 361 his Caesar and cousin Julian, soon to be known as 'the Apostate', became sole Augustus and ruled the empire for almost three years (from December 361 to June 363). ${ }^{1}$ As suggested by at least some of the extant evidence, though this is not yet widely recognised by modern scholars, Julian conceived of his reign as a kind of purification from the plague of atheism, by which he meant the ever increasing influence of Christianity under imperial patronage. ${ }^{2}$

My paper will analyse the role played by Judaism and its purity legislation in the charges levelled against Christians in Julian's 'Against the Galileans'. I will focus on two main strands of Julian's argument: the similarity between Hellenism and Judaism, as perceived by Julian, and the impurity of the Christians resulting

\footnotetext{
${ }^{1}$ Julian's brief and controversial reign represents one of the best documented chapters of later Roman history and hence one of the most studied. In addition to the classic J. Bidez, La vie de l'empereur Julien, Paris 1930, compare also R. Browning, The Emperor Julian, London 1975; G.W. Bowersock, Julian the Apostate, London 1978 and P. Athanassiadi, Julian and Hellenism: An Intellectual Biography, London 1981. For an up to date general and exhaustive presentation with a rich bibliography see K. Rosen, Kaiser, Gott und Christenhasser, Stuttgart 2006, the most excellent monography on Julian presently available. On his thought see also R. Smith, Julian's Gods: Religion and Philosophy in the Thought and Action of Julian the Apostate, London 1995.

${ }^{2}$ The central position which 'purity' plays in Julian's thought and action has been analysed in

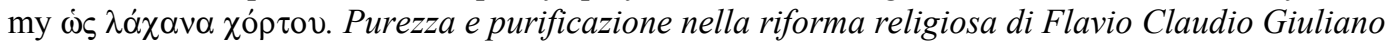
(361-363 d.C.), Diss. Pisa, 2007. For a general introduction to the subject of purity see Pureté et impureté. I. L'Histoire des religion, in Supplément au Dictionnaire de la Bible 19, 398-430.
}

Giorgio Scrofani, “"Like Green Herbs”: Julian’s Understanding of Purity and His Attitude 
from their refusal of Jewish sacrificial practice and dietary regulations. Against a widespread view, I will argue firstly: that Judaism plays essentially a polemical role in Julian's definition of boundaries between Christians and Hellenes; and secondly that although Neoplatonic influence, in the matter of sacrifice and purity, can neither be denied nor underestimated in Julian, Neoplatonism only supplies the intellectual-philosophical justification, and not the source, for ancient cultic practices shunned by 'Christian atheists'. Finally, I will suggest that contrary to a leading opinion, as recently expressed by Guy Stroumsa in his La fin du sacrifice, defilement and purity in Late Antiquity should not be considered only in terms of a spiritual condition, but also in political and cultic terms. ${ }^{3}$

\section{Jewish and Hellenic Piety in 'Against the Galileans': C. Gal. fr. 72}

In the Contra Heraclium and in the Caesares Julian suggests that Constantine and his sons subverted human and divine laws alike. They neglected the traditions of their ancestors and betrayed the divinely providential mission of Rome to follow Christian doctrine. Thus Julian understood his imperial election as a divine call to restore the empire. ${ }^{4}$ The ethical, intellectual and political opposition to the plague spread in the empire by Christians, which characterises Julian's entire literary production and political action, ${ }^{5}$ would have found a coherent theoretical expression in his three books Contra Galilaeos. Of this work, composed during his stay at Antioch between June 362 and March 363, ${ }^{6}$ only a few fragments of the first book survive in the fifth century Contra Iulianum of Cyril of Alexandria. ${ }^{7}$ The proper

\footnotetext{
${ }^{3}$ G. Stroumsa, La fin du sacrifice: les mutations religieuses de l'antiquité tardive, Paris 2005, 88.

${ }^{4}$ C. Heracl. 227c-234c. The divine order given to Julian to purify the empire from all the stain accumulated by his predecessors has to be intented as a sort of palingenesis, involving the empire in all its aspects as marginally argued by I. Tantillo, L'imperatore Giuliano, Roma-Bari 2001, 81 and Rosen, Kaiser $231 \mathrm{ff}$. Julian accomplished this task as pontifex maximus appointed by the divinity according to Roman traditions. Cf. infra.

${ }^{5}$ I refer here especially to the law de doctoribus et magistris (ep. $61 \mathrm{~b}=$ Cod. Theod. XIII, 3,5) and to the later edict de Sepulchris et funeribus (ep. 136a = Cod. Theod. IX, 17, 5). On Julian's policy against Christians see Rosen, Kaiser $235 \mathrm{ff}$. and related bibliography.

${ }^{6}$ Compare Libanius, Or. XVIII, 178.

${ }^{7}$ Following the anti-Christian topics developed by Celsus and Porphyry Julian's argumentation focuses on the concept of revelation, the fallacy of Jewish theology and the allegorical interpretation of Scriptures supported by Christians. The exegetical work undertaken in Contra Galilaeos is anticipated by epp. 90, 106 and 107; for a comparison of Julian's work with the Against the Christians of Porphyry see A. Meredith, Porphyry and Julian Against the Christians, ANRW II, 23.2 (1981) 1119-1149 (esp. 1138-1140); W. Hargis, Christian Exclusivism and the Formation of Early antiChristian Discourse in Celsus, Porphyry, and Julian, Thesis (Ph.D.), Temple University, Philadelphia (Pa.) 1998. For its philosophical argumentation see C. Riedweg, 'With Stoicism and Platonism against the Christians: Structures of philosophical Argumentation in Julian's Contra Galilaeos ,' Hermathena 166 (1999) 63-91. On the text of Contra Galileos see E. Masaracchia, Giuliano Imperatore. Contra Galilaeos. Introduzione, testo critico e traduzione a cura di Emanuela Masaracchia, Roma 1990, 13-71. For its sources, J. Bouffartigue, L'empereur Julien et la culture de son temps, Paris 1992, 379-385. On the Contra Iulianum see further J. W. Malley, Hellenism and Christianity, Rome 1978, 237-423. Other fragments of the Contra Galilaeos are quoted by Theodore of Mopsuestia in his Against Julian. Compare A. Guida, Teodoro di Mopsuestia. Replica a Giuliano imperatore. A cura di Augusto Guida, Florence 1994, 193-225.
}

Giorgio Scrofani, “"Like Green Herbs": Julian's Understanding of Purity and His Attitude Towards Judaism in His Contra Galilaeos,' in: Journal for Late Antique Religion and Culture 2 (2008) 1-16; ISSN: 1754-517X; Website: http://www.cardiff.ac.uk/clarc/jlarc.html 
way to understand the 'Against the Galileans' is to see it in the context of Julian's policy not just as a simply apologetic/polemical work. ${ }^{8}$ Julian's aim is to show that Christians, who pretend to be the true Israelites according to their prophets, are instead in a double sense apostates: for indeed they refused at once the Jewish Law and Hellenic worship. ${ }^{9}$ In line with Celsus and Pophyry Julian aims at the core of Christian identity: He questions their interpretation of Scripture. The Christians, he argues, are not a third ethnos, as claimed by Eusebius, distinguished from and superior to Jews and Greeks. ${ }^{10}$ They are just Galileans, adherents to a peripheral apostasy, who not deserve to be called either Jewish or Greek. ${ }^{11}$

Although in Julian's view Judaism itself deserves criticism, because of its weak theology and absurd election claim (and its manifest inferiority), Galileans would

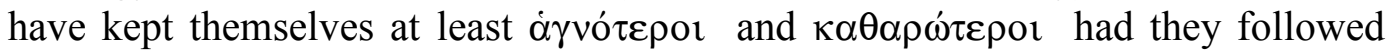
the Law of Moses. Instead they abandoned the pure and priestly life of Jews to follow a new doctrine. ${ }^{12}$ In doing so they accomplished everything that was abhorred by Moses. The key to understanding the meaning of Julian's argumentation is given in $C$. Gal. fr. 72:

Jews agree with the Gentiles, except that they believe in only one God. That is indeed peculiar to them and strange to us; since all the rest we have in a manner in common with them, temples, sanctuaries, altars, purifications ( $\dot{\alpha} \gamma v \varepsilon i \alpha \imath)$ and certain precepts. For as to these we differ from one another not at all or in trivial matters. ${ }^{13}$

To show how the Galileans set themselves apart not only from the idea of piety

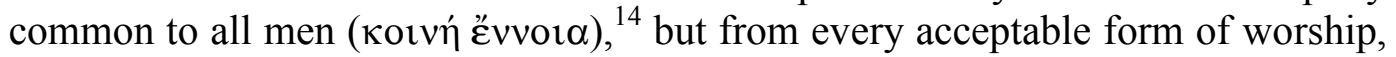
Julian strategically develops a close parallelism between Jews and Hellenes. The religion of the patriarchs and the Law of Moses, even though they represent only an inferior stage to Greek tradition, possess nevertheless the validity of an ancient tradition: their origins are linked through Abraham, Isaac and Jacob to the Chaldeans,

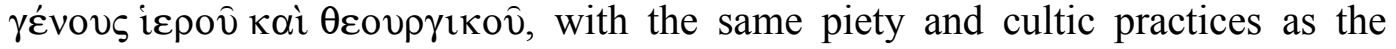

\footnotetext{
${ }^{8}$ Cf. P. Évieux, 'De Julien à Cyrille. Du Contre les Galiléens au Contre Julien,' in B. Pouderon - J. Doré (ed.), Les Apologistes chrétiens et la culture grecque. Actes du colloque de Paris, septembre 1996, organisé par l'Université de Tours et l'Institut catholique de Paris, Paris 1998, 355-368 (364).

${ }^{9}$ C. Gal. fr. 3. Hereinafter fragments are numbered as in the critical edition by E. Masaracchia; trans. W.C. Wright, The works of the emperor Julian, vol. III, London 1923.

${ }^{10}$ The second century apologetical motif of Christianity as a 'third ethnos' was recovered and developed by Eusebius of Caesarea in his twofold work Praeparatio Evangelica and Demonstratio Evangelica, problably composed during the Great Persecution in response to Porphyry's 'Against Christians'. On Ethnic argumentation in Eusebius see A.P. Johnson, 'Identity, Descent, and Polemic: Ethnic Argumentation in Eusebius' Praeparatio Evangelica,' JECS 12 (2004) 23-56.

${ }^{11}$ Compare Porphyry, C. Christ. fr. 1 . The term 'Galileans' goes back to Epictetus, Dissert. IV, 7, 6. For its use by Julian see S. Scicolone, 'Le accezioni dell'appellativo Galilei in Giuliano,' in: Aevum 56 (1982) 71-80. They cannot be called even Christians because they subverted in many ways the original teaching of Jesus as in $C$. Gal. frr. 48; 81; compare Porphyry, C. Christ. fr. 7.

${ }^{12}$ C. Gal. frr. 47, 11-13; 58, 9-11; compare also Celsus apud Origen, C. Cels. V, 25.

${ }^{13}$ Compare ep. 89a, 453d-454b. Here Jews are praised in opposition not to Christians but to the Hellenes. However, such superiority is only provisional. Indeed it is mainly due to the fact that the Hellenes are not actually interested in Judaism.

${ }^{14}$ C. Gal fr. 7; compare Celsus apud Origen, C. Cel. VIII, 38; Porphyry, C. Christ. fr. 1,3-4; and Iamblichus, Myst. I,3.
}

Giorgio Scrofani, "Like Green Herbs": Julian's Understanding of Purity and His Attitude Towards Judaism in His Contra Galilaeos,' in: Journal for Late Antique Religion and Culture 2 (2008) 1-16; ISSN: 1754-517X; Website: http://www.cardiff.ac.uk/clarc/jlarc.html 
Greeks. ${ }^{15}$ Once such an equation is established, Galilean infractions of Jewish norms will correspond to the infraction of the analogous Hellenic practices. To defraud Christians of Jewish Scriptures and prophecies, Julian claims the Jewish heritage as something really close to paganism, not to Christianity: Christians, he argues, are not similar to Jews, but Jews are similar to Greeks. Jews are $\kappa \alpha \theta \alpha \rho o$, and consequently Hellenes too. Their siat $\tau \alpha$ is proof of proper cultic behaviour, against the Galileans' $\kappa \alpha \iota v o \tau o \mu i \alpha$, their carelessness regarding the mosaic Law, which they declared abolished by the coming of Christ. ${ }^{16}$

\section{Christian Betrayal of the Jewish Feast of Yom Kippur and of the Dietary Laws}

This latter charge is concretised in a discussion about expiatory and purificatory

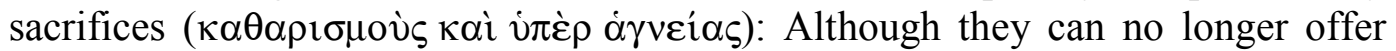
blood sacrifices because of the destruction of the Jerusalem Temple, Jews, thus

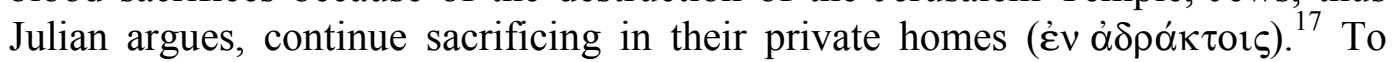
prove that Moses was far from considering sacrifices polluting acts in the way Christians do Julian refers to the day of Atonement as described in Leviticus 16:

And now observe again how much Moses says about the sacrifices that avert evils ( $\left.\dot{v} \pi \dot{\varepsilon} \rho \delta \dot{\varepsilon} \dot{\alpha} \pi \mathrm{o} \tau \rho \alpha_{\alpha} \dot{i} \omega v\right)$ : 'And he shall take two he-goats of the goats for a sinoffering, and one ram for a burnt offering. And Aaron shall bring also his bullock of the sin-offering, which is for himself, and make an atonement for himself and for his house. And he shall take the two goats and present them before the Lord at the door of the tabernacle of the covenant. And Aaron shall cast lots upon the two goats; one for the Lord and the other lot for the scapegoat,' so to send him forth, says Moses, as a scapegoat, and let him loose into the wilderness. Thus then is sent forth the goat that is sent for the scapegoat. And of the second goat Moses says: 'Then shall he kill the goat of the sin-offering that is for the people before the Lord, and bring his blood within the veil, and shall sprinkle the blood upon the altar-step and shall make an atonement for the holy place, because of the uncleanness of the children of Israel and because of their transgressions in all their sins.' Thus it is evident from what has been said that Moses knew the various methods of sacrifice. ${ }^{18}$

\footnotetext{
${ }^{15}$ C. Gal. fr. 86; 87; compare Porphyry, C. Christ. fr. 4.

${ }^{16}$ Julian, it appears, displays no particular interest in the rabbinic Judaism of his time, although he is clearly aware of some of its features; against D. Borrelli, 'In margine alla questione ebraica in Giuliano Imperatore,' Koinonia 24 (2000) 95-116: he focuses only on the Law as shared heritage of Jews and Christians. On Julian's knowledge of Judaism and Jewish Scriptures see Bouffartigue, 1992, 683-684.

${ }^{17}$ C. Gal. fr. 72.

${ }^{18}$ C. Gal. fr. 70. The rite is also described in Lev 23, 26-32 and Num 19, 7-11. On the meaning of Yom Kippur see J. Milgrom, Leviticus 1-16: A new Translation with Introduction and Commentary, London 1991, passim; M. Pesce - A. Destro, 'Il rito ebraico di Kippur: Il sangue nel tempio, il peccato nel deserto,' in G. Galli (ed.), Interpretazione e Perdono. Atti del Dodicesimo Colloquio sull'interpretazione (Macerata, 18-19 marzo 1991), Genova 1992, 47-73; M. Douglas, Leviticus as Literature, Oxford 1999, 208-51. Biblical expiatory rituals are analysed by J. Klawans, 'Pure Violence: Sacrifice and Defilement in Ancient Israel,' in: HTR 94 (2001) 135-157 and M. Pesce, 'Gesù e il sacrificio ebraico,' in: ASE 18 (2001) 129-168 (133-144). A recent contribution on the rabbinic interpretation of the Yom Kippur ritual can be found in J. Neusner, 'Sacrifice in Rabbinic Judaism: 
Julian quotes almost verbatim (with the only exception of $\tau \rho \alpha$ ó $\gamma$ s instead of $\chi$ í $\mu \rho \rho_{\varsigma}$ in Lev $\left.16,5,15\right)$ the Biblical text describing the two central moments of the ritual procedure to follow during the Yom Kippur as described in the book of Leviticus: The aim of the procedure is to purify the Sanctuary, sprinkling it with the blood of the sacrificed goat, and to remove the sins from Israel's children confessing them on to the head of the goat for it to be sent into the wilderness. Julian is, as far as I know, the only pagan ever to refer expressly to the Day of Atonement ritual (and not generically to the Sabbath or other festivities, as for example Plutarch or Juvenal). ${ }^{19}$ This has a precise reason. For Christians the law of the 'old covenant' was no longer valid as law after the coming of their saviour. They therefore interpreted the atonement ritual typologically and allegorically as a pre-figuration of Christ's death for human sake. As Julian himself states (quoting the New Testament): 'Jesus was sacrificed once for all. ${ }^{20}$ After a development of biblical exegesis that had started in the first century, Christian theologians of the fourth century massively employed templar imagery to describe Church liturgy. ${ }^{21}$

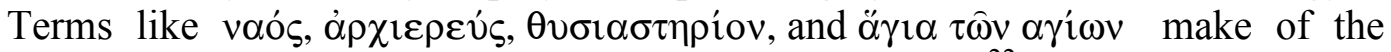
Eucharistic celebration an authentic atonement sacrifice: ${ }^{22}$ indeed, Jesus' death and resurrection revealed the real meaning of the Day of Atonement ritual. This 'templarization' is strengthened by the opposition to Judaizing Christians: it is by attending Christian liturgies, confessing sins, celebrating the Eucharistic sacrifice, and by bearing witness through asceticism and martyrdom, and not by fasting like the Jews that men achieve spiritual purification from their moral impurities and expiate their sins. ${ }^{23}$

For Julian, the Christians, by abolishing the sacrifices which were practised by the Jews since Abraham, and by replacing them with the notion of the one and unrepeatable sacrifice of Christ, have rid themselves from the chance of expiating their misdeeds and get purified. The water which they use for washing off their sins has no meaning and value (as Julian shows in the 'Caesars' and in 'Against

The Presentation of the atonement-rite of sacrifice in Tractate Zebahim in the Mishnah, Tosefta, Bavli, and Yerushalmi,' in: ASE 18 (2001) 225-253.

${ }^{19}$ See F. Millar, 'Jews of the Graeco-Roman Diaspora between Paganism and Christianity, AD 312-438,' in J. Lieu - J. North - T. Rajak eds., The Jews among Pagans and Christians in the Roman Empire, London 1992, 97-123, 106-108; P. Schäfer, Judeophobia. Attitudes toward the Jews in the Ancient World, Cambridge 1997, 82-92.

${ }^{20}$ Christians did not reject the very idea of sacrifice but considered Jesus' death the ultimate sacrifice. See for example 1Cor 5,7; 2Cor 5, 17-21; John 1, 29; 1 Pet 2, 23; 1 Jn 2, 2; 4, 10. On this topic C. Grottanelli, 'Appunti sulla fine dei sacrifici ,' in: EVO 12 (1989) 175-192; J.D.G. Dunn, 'Paul's Understanding of the Death of Jesus as sacrifice,' in S. W. Sykes ed., Sacrifice and Redemption, Cambridge 1991; P. Lampe, 'Human Sacrifice and Pauline Christology,' in K. Finsterbusch - A. Lange - K.F. Diethard Römheld ed., Human Sacrifice in Jewish and Christian Tradition, Leiden-Boston 2007, 191-209.

${ }^{21}$ The Day of Atonement was interpreted as a christological metaphor at least since the Epistle to the Hebrews (in the early second century), as transition from the old to the new covenant, from flesh to spirit; cf. Hebrews 8, 3; 9, 12-14; 10, 1-4. See further Chester 1991.

${ }^{22}$ As in Tert. Bapt. 17,1; Eus. v. Const. 3, 28; Greg. Naz. Or. X, 4.

${ }^{23}$ Compare F. Young, The Use of Sacrificial Ideas in Greek Christian Writers from the New Testament to John Chrysostom, Cambridge 1979; D. Stöckl Ben Ezra, The Impact of Yom Kippur on Early Christianity, Tübingen 2003.

Giorgio Scrofani, "'Like Green Herbs": Julian's Understanding of Purity and His Attitude Towards Judaism in His Contra Galilaeos,' in: Journal for Late Antique Religion and Culture 2 (2008) 1-16; ISSN: 1754-517X; Website: http://www.cardiff.ac.uk/clarc/jlarc.html 
the Galileans'). ${ }^{24}$ Writing to the inhabitants of Bostra in August 362 (ep. 114), Julian affirms that Christians who return to the worship of the Gods have to be purified in advance. Before taking part in the ceremonies they must purify their soul by public prayers, and their body through purifications. ${ }^{25}$

As further evidence for a Christian rejection of the Jewish Law Julian cites the refusal to distinguish between pure and impure animals, as witnessed in the story of the vision of Peter in the book of Acts: ${ }^{26}$

\begin{abstract}
Why in your way of life are you not as pure ( $\left.\kappa \alpha \theta \alpha \rho)^{\prime}\right)$ as the Jews, and why do you

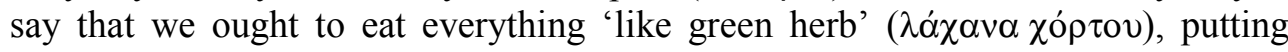
your faith in Peter, because, as you say, he declared, 'What God has cleaned, that

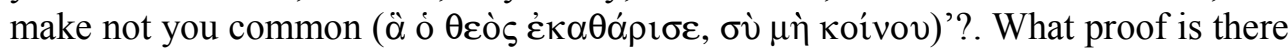

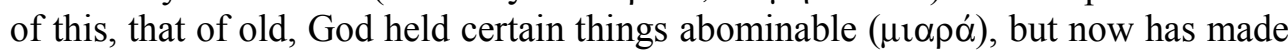
them pure ( $\kappa \alpha \theta \alpha \rho \alpha$ ) $)$. For Moses, when he is laying down the law concerning four footed-things, says that whatsoever parts the hoof and is cloven-footed and chews

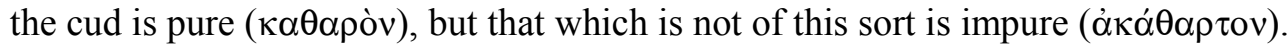
Now if, after the vision of Peter, the pig has now taken to chewing the cud, then let us obey Peter; for it is in very truth a miracle if, after the vision of Peter, it has taken that habit. But if he spoke falsely when he said that he saw this revelation - to use your own way of speaking - in the house of the tanner, why are we so ready to believe him in such important matters? Was it so hard a thing that Moses enjoined on you when, besides the flesh of swine, he forbade you to eat winged things and things that dwell in the sea, and declared to you that besides the flesh of swine these also

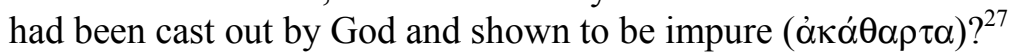

The interpretation of Jewish purity laws represents one of the main differences between Judaism and Christianity. To sum up briefly a very complex question: In the priestly theology of Leviticus, purity is requested as the main precondition to have contact with holiness (in the priestly view everything that belongs to YHWH must be considered holy, even Jewish people: holiness is thus a quality acquired by things and human beings through proximity with God): it involves absence of impurity. The latter is perceived mainly, but not in all the traditional strata, as a substance transmittable by contact, an impersonal force not relating to moral behaviour. ${ }^{28}$ The Jesus movement, as other Jewish groups of the same period, came

\footnotetext{
${ }^{24}$ Julian criticizes Christian baptism directly in C. Gal. fr. 59, 10-23 as well as indirectly, e. g. with reference to Constantine's conversion in Caes. 336a-c. For pagan criticism of baptism see G. Urso, 'Purificazione e perdono: una polemica fra pagani e cristiani,' in M. Sordi ed., Responsabilità perdono e vendetta nel mondo antico, Milano 1998, 249-266.

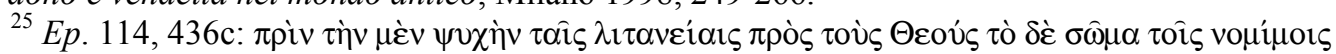
$\kappa \alpha \theta \alpha \rho \sigma i o r \varsigma \kappa \alpha \theta \dot{\rho} \rho \alpha \sigma \theta \alpha$. The letter, sent to the citizens of Bostra in the summer of 362 , is the public answer to Titus, the local bishop, who had asked for imperial intervention in the growing conflicts between pagans and Christians. Although it accuses the bishop as the one really responsible for the strife, it is a manifest of Julian's policy of tolerance. For an analogous letter attributed to Constantine see Eusebius, v. Const. II, 56, 1-2. According to Greg. Naz. Or. IV, 55 Julian subjected himself to a bloody purification ritual to wash off the stain of Christian Baptism. Cf. also C. Heracl. 230c-d.

${ }^{26}$ Acts $10,11-15$.

${ }^{27}$ C. Gal. fr. 74.

${ }^{28}$ On the topic see e.g. J. Neusner, The Idea of Purity in Ancient Judaism, Leiden 1973; Milgrom, 1991, passim; J. Klawans, Impurity and Sin in Ancient Judaism, Oxford 2000. Specifically on dietetic
}

Giorgio Scrofani, "'Like Green Herbs": Julian's Understanding of Purity and His Attitude Towards Judaism in His Contra Galilaeos,' in: Journal for Late Antique Religion and Culture 2 (2008) 1-16; ISSN: 1754-517X; Website: http://www.cardiff.ac.uk/clarc/jlarc.html 
in conflict with the priestly interpretation and its amoral automatism, stressing the ethical and moral aspect of the concept of purity. ${ }^{29}$ New Testament traditions bear witness to tensions in the community in this field. See for example the so called council of Jerusalem in Acts and its conciliatory solution to admit Gentiles in the Jesus community. ${ }^{30}$ A more unitary attitude will be reached only in the second half of the second century, after the formation of a New Testament Canon and of the typological interpretation of the Old Testament. Christians interpreted many statements attributed to Jesus in the light of Pauline 'anti-legalism', for example Mt 15,11: 'What goes into a man's mouth does not make him unclean, but what comes out of his mouth, that is what makes him unclean. ${ }^{31}$

The report of Peter's vision in Acts too belongs in this context. It was one of the most ancient and authoritative attestations of the end of Mosaic law in the field of purity. The passage describes how in an ecstatic state Peter received from God the command to abolish all dietary laws of the past: 'What God has cleaned that make

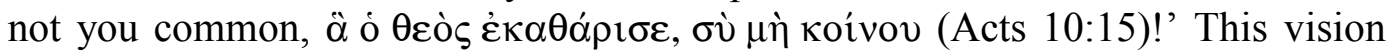
justifies the passage from ritual observance to Christian-Pauline spiritualization and explains the origin of the gospel diffusion among Gentiles, which many Jews experienced as impure. ${ }^{32}$ This is where Julian locates his argument: Even if Moses once and again declared the Law eternal and untouchable, he points out, Galileans devour everything like green herb following Jesus' habits, i. e. the habits of a man who was in fact charged by the Pharisees to be a drunkard and a heavy eater. ${ }^{33}$

Already in the discourse 'To the Uneducated Cynics' Julian accuses his anonymous interlocutor, who despises Diogenes' alimentary habits, of being an Egyptian, not of the priestly caste but of the omnivorous type, whose habit is to eat everything

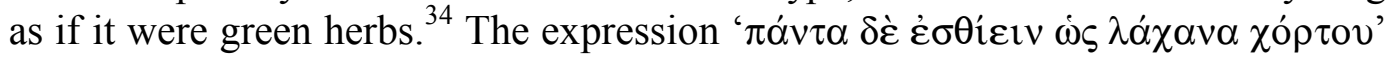
refers to the words spoken by God to Noah after the deluge in Genesis 9:3: 'Every moving thing that lives shall be food for you; and just as I gave you the green plants, I

regulations see I. Grunfeld, The Jewish Dietary Laws, London 1973; M. Douglas, 'The forbidden Animals in Leviticus,' in: JSOT 59 (1993) 3-23, 85-104; W. Houston, Purity and Monotheism: clean and unclean Animals in biblical Law, Sheffield 1993; J. Moskala, 'Categorization and Evaluation of different Kinds of Interpretation of the Laws of clean and unclean Animals in Leviticus 11,' in: Biblical Research 46 (2001) 5-41.

${ }^{29}$ For a survey of Jesus' attitude toward purity see J.G.D. Dunn, 'Infected Sheep and Diseased Cattle, or the pure and holy Flock: Cyprian's pastoral Care of Virgins,' in: JECS 11 (2003) 1-20; for purity in early Christianity M. Newton, The Concept of Purity at Qumran and in the Letters of Paul, Cambridge 1985; M. Pesce - A. Destro, 'La normativa del Levitico: interpretazioni ebraiche e protocristiane,' in: ASE 13 (1996) 15-37; G. Rouwhorst, 'Leviticus 12-15 in Early Christianity,' in M. J. H. M. Poorthuis - J. Schwartz eds., Purity and Holiness. The Heritage of Leviticus, LeidenBoston-Köln 2000, 181-193; P. Tomson, 'Jewish Purity Laws as Viewed by the Church Fathers and by the Early Followers of Jesus,' in M.J.H.M. Poorthuis - J. Schwartz eds., Purity and Holiness. The Heritage of Leviticus, Leiden-Boston-Köln 2000, 73-91.

${ }^{30}$ Acts 15, 28-29. For a full analysis of the decree and its fortune in history see M. Simon, 'De l'observance rituelle a l'ascèse: recherches sur le Décret Apostolique,' in: RHR 193 (1978) 27-104.

${ }^{31}$ Cf. M. Simonetti, 'Cenni sull'interpretazione patristica di Mt 15,11,' in: ASE 13 (1996) 113-122.

${ }^{32}$ On Gentile impurity from a Jewish perspective cf. C.E. Hayes, Gentile Impurities and Jewish Identities. Intermarriage and Conversion from the Bible to the Talmud, Oxford 2002.

${ }^{33}$ C. Gal. fr. 97.

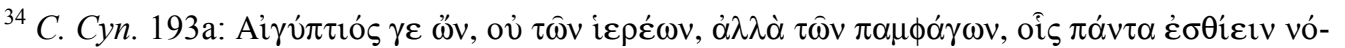

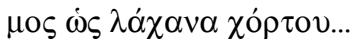

Giorgio Scrofani, "'Like Green Herbs": Julian's Understanding of Purity and His Attitude Towards Judaism in His Contra Galilaeos,' in: Journal for Late Antique Religion and Culture 2 (2008) 1-16; ISSN: 1754-517X; Website: http://www.cardiff.ac.uk/clarc/jlarc.html 
give you everything. Only, you shall not eat flesh with its life, that is, its blood. ${ }^{35}$ At least since Justin Martyr in his 'Dialogue with Trypho' (around the middle of the second century) this passage has been interpreted by early Christian writers as proof of the uselessness of Mosaic dietary prescriptions for Christians: if the pious Noah was allowed to eat everything, except flesh with blood, Moses was forced to give the Law to Jews because of their indolence and weakness. ${ }^{36}$ Citing the book of Genesis, Julian puts Christian allegorical interpretation in context and, at the same time, stresses its feral nature.

\section{The Meaning of Jewish Tradition in 'Against the Galileans'}

According to a leading opinion this positive evaluation of Jewish practices in the Contra Galilaeos is an expression of Julian's ritualism and anti-Christian policy: Indeed, so it is argued, Julian needed and sought the support of the Jewish community as an ally against the Christians and counted on their practical help against the Persians. ${ }^{37}$ Moreover, the decision to rebuild the Jerusalem temple would have undermined one of the main Christian theological principles (the end of ancient Israel and the fulfilment of the prophecies) and conferred renewed prestige to the Jewish people. ${ }^{38}$ Even though such an instrumentalization is undeniable, modern scholars have overlooked, in my opinion, its actual function in the context of Julian's thought and political action.

In this context any reference to Jewish practices makes sense only in so far as it evokes and reflects Hellenic practices. The Christian spiritual interpretation of the

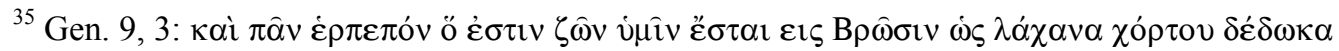

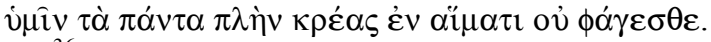

${ }^{36}$ See Iustin. Dial. 20, 2-3; Greg. Nyss. Creat. 50,5; Basil. ep. 236,4,4; Ioh. Chrys. Hom. Gen. $53,245,38$. On Noachic commandments in Early Christianity M. Bockmuehl, Jewish Law in Gentile Churches. Halakhah and the Beginning of Christian Public Ethics, Edinburgh 2000, 145-173.

${ }^{37}$ The alliance with Judaism has been a dominant feature of Julian's portrait since his Christian opponents first attributed it to him (cf. Greg. Naz. Or. V, 3; Ioh. Chrys. Adv. Jud. 5,11; Ambr. ep. 40; Socrat. Hist. Eccl. III, 20; Sozom. Hist. Eccl. V, 22,1; Teod. Hist. Eccl. III, 20). It is almost unanimously accepted by modern scholars. Cf. Bowersock, 1978, 89; M. Simon, Verus Israel: Relations entre juifs et chrétiens dans l'empire romain (135-425), Paris 1986 ${ }^{4}$, 142-143; N. Belayche, “"Partager la table des dieux ": l'empereur Julien et les sacrifices,' in: RHR 218 (2001) 457-486, 476; Rosen, 2006, 328.

${ }^{38}$ See e.g. Athanassiadi, 1981, 164; Borrelli, 2000, 112. For the rebuilding of the Temple, testified by ep. 89a, 295c; ep. 134; ep. 204; Amm. Marc. XXIII, 1, 2-3. N. Blanchetière, 'Julien philellène, philosémite, antichrétien: L'affaire du Temple de Jerusalem,' in: JJS 31 (1980) 61-81, 5260; for a detailed analysis of the literary sources J.W. Drijvers, 'Ammianus Marcellinus 23, 1, 2-3: The Rebuilding of the Temple in Jerusalem,' in J. den Boeft (ed.), Cognitio Gestorum: The Historiographic Art of Ammianus Marcellinus, Amsterdam 1992, 19-26; R.J. Penella, 'Emperor Julian, the temple of Jerusalem and the god of the Jews,' in: Koinonia 23 (1999) 15-31; J. Hahn, 'Kaiser Julian und ein dritter Tempel? Idee, Wirklicheit und Wirkung eines gescheiterten Projektes,' in: J. Hahn (ed.), Der Jerusalemer Tempel und seine Zerstörungen, Tübingen 2002, 237-262; Rosen, 2006, 328-331. Indeed a new Temple would have destroyed the theological claim of the Christians to be the New Israel, according to which God lets Jerusalem and its Temple be destroyed because Jews are unfaithful, having rejected Jesus'offer of salvation as mentioned by Julian himself in ep. 89a, 295d. See further Penella, 1999, 16 ff.
}

Giorgio Scrofani, “"Like Green Herbs”: Julian's Understanding of Purity and His Attitude Towards Judaism in His Contra Galilaeos,' in: Journal for Late Antique Religion and Culture 2 (2008) 1-16; ISSN: 1754-517X; Website: http://www.cardiff.ac.uk/clarc/jlarc.html 
sacrifice and of the purity of heart as a way of life freed by passions elevating the human soul to God was nothing new. It rooted in a long lasting tradition not only in certain sectors of Judaism (such as the Qumran community or Hellenistic / Diaspora Judaism not to mention the so-called Rabbinic Judaism) but also in GraecoRoman philosophy. This is not the place to elaborate on the criticism directed by Greek and Roman intellectuals at a kind of worship that was perceived as purely exterior. ${ }^{39}$ An example for such a position from the early fourth century was Porphyry's 'On Abstinence'. Like many Christians of his time Porphyry understood the traditional religious elements (temple, altar, sacrifice) allegorically, as pertaining to the purification of the philosopher's soul from passions (though unlike them he stated the importance of the conventional civic cult (Abst. I, 27, 1)). In his letter to his wife Marcella he refers to inner sacrifice, purification from passions and intel-

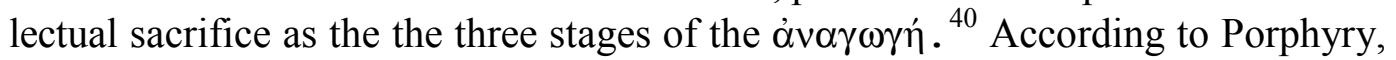
authentic purification, inner and outward ( $\left.\dot{\eta} \varepsilon \varepsilon_{\sigma} \sigma \omega \kappa \alpha \grave{i} \dot{\eta} \dot{\varepsilon} \kappa \tau \grave{s} \varsigma \dot{\alpha} \gamma v \varepsilon \dot{\alpha} \alpha\right)$, is achieved

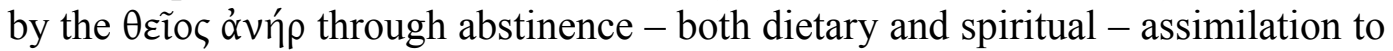

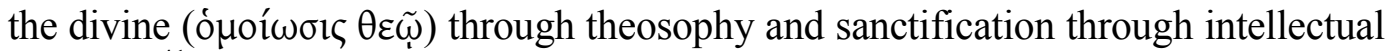
sacrifice. ${ }^{41}$ As Scott Bradbury has underlined, Porphyry's 'On Abstinence' is not an assault on traditional worship, but an attempt to persuade a friend of the utility of a vegetarian diet for a philosopher. It is vital to understand the rhetorical dimension of Porphyry's argument in 'On Abstinence'; and it is also important to note in this context that Porphyry's later works, like the 'Epistle to Marcella' and his 'Against Christians', were written against a background of increasing tension between Roman authority and Christianity. They seem to show an increasingly conservative attitude to traditional worship emphasizing the fundamental value of the latter. ${ }^{42}$ At any rate, with its deep philosophical motivation and its various examples of bloodless worship, Porphyry's argument seems to have been perceived as potentially so attractive to Christians that church writers such as Eusebius and Cyril of Alexandria saw the need to refute it emphatically, and in detail. ${ }^{43}$

But Porphyry had pagan critics too. Iamblichus, as is well known, rejected his vegetarianism. Iamblichus' arguments against Porphyry can be found developed mainly in the fifth book of his 'On Mysteries'. Maintaining a distinction between spiritual and material worship ${ }^{44}$ Iamblichus thought of blood sacrifices as a way of entering theurgically into a union with the gods; for blood sacrifices, he argued, create a bond between the gods and the material substance, over which the gods

\footnotetext{
${ }^{39}$ For an introductory survey on this topic see E. Ferguson, 'Spiritual sacrifice in early Christianity and its environment,' in: $A N R W$ II 23.2 (1980) 1151-1189.

${ }^{40}$ Ad Marc. 26.

${ }^{41}$ Abst. II 45,4. See S. Tolouse, 'La Théosophie de Porphyre et sa conception du sacrifice intérieure, in S. Georgoudi - R. Koch Piettre - F. Schmidt (eds.), La cuisine et l'autel. Les sacrifices en questions dans les sociétes de la Méditerranée ancienne, Turnhout 2005, 329- 341.

${ }^{42}$ S. Bradbury, 'Julian's pagan revival and the decline of blood sacrifice,' in: Phoenix 49 (1995) 331-356.

${ }^{43}$ Eus. Praep. V, 10, 1; Cyrill. C. Iul. II, 37, 280. Cf. Theodor. Affect. III, 66; Aug. Civ. X, 11.

${ }^{44}$ Myst. V, 15, 12-17; 22. Spiritual sacrifice belongs only to philosophers who are able to purify their soul from bodily restraints. Corporal sacrifice is the one practiced by all those whose soul is still imprisoned by their body. Such a dualism depends on human nature, corporal and spiritual at the same time. G. Shaw, Theurgy and the Soul: The Neoplatonism of Iamblicus, University Park 1995, 148-150; Stroumsa, 2005, 179 ff.
}

Giorgio Scrofani, “"Like Green Herbs": Julian's Understanding of Purity and His Attitude Towards Judaism in His Contra Galilaeos,' in: Journal for Late Antique Religion and Culture 2 (2008) 1-16; ISSN: 1754-517X; Website: http://www.cardiff.ac.uk/clarc/jlarc.html 
preside. The gods, thus Iamblichus further, cannot be polluted by the smoke rising up from the sacrifices, as Porphyry claimed, because their very essence is purity. ${ }^{45}$ Rather, the fire that consumes the sacrifices purifies ( $\dot{\alpha} \gamma \varepsilon \varepsilon v \varepsilon$ ) their matter turning

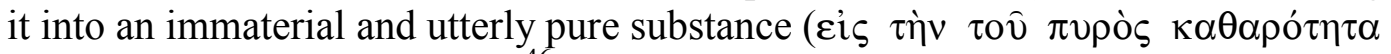

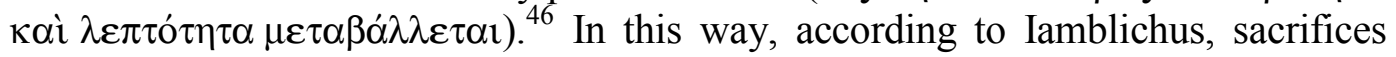
could eventually assume an expiatory and purificatory role, even for the body; for

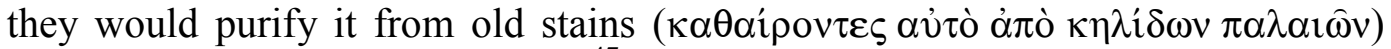
and heal it from illnesses (vóбot). ${ }^{47}$ According to Iamblichus, then, it was not so much a useful or viable option to perform corporeal sacrifices. Rather, sacrifices had to be corporeal $(\sigma \omega \mu \alpha \tau o \varepsilon \imath \delta \eta \dot{\eta})$ in order to do justice to the corporeal nature of the body, which by itself did not participate in the spiritual substance and was therefore relying on some sort of mediation. ${ }^{48}$

Julian, for his part, recognised spiritual sacrifice as the supreme offering to the deity. Nevertheless, when explaining in 'Against the Galileans' the biblical episode of Cain and Abel, he states, very much like Iamblichus, that animated beings are preferred by the gods because they participate in life. ${ }^{49}$ Accordingly, he argues, the best form of sacrifice is therefore the blood sacrifice subordinated to justice and virtue. ${ }^{50}$ The revival of blood sacrifices under Julian, as attested by Ammianus, Libanius and many other later sources (after Constantius had effectively banned them in 354$)^{51}$ is often put down to Neoplatonist influence upon Julian. However, modern studies have tended to exaggerate this influence. ${ }^{52}$ Iamblichus, mediated by his disciples, provided the intellectual justification for blood sacrifice, but it was politics, as much as piety, that moved Julian in this direction. ${ }^{53}$ Before being a Neoplatonist he was a Greek and a Roman, indeed he was the pontifex maximus of Rome. ${ }^{54}$ As Nicole Belayche has recently recognised, the intellectual debate about the necessity of blood sacrifices or their substitution by spiritual ones had not really affected actual practice. Even if despised by Porphyry and Christians, limited by Constantine and temporarily banned by Constantius, blood sacrifice preserved its role as the central rite of Roman, and Greek, cult. Even in the fourth century it was seen as an essential means to preserve the ordo rerum. ${ }^{55}$ Writing to

${ }^{45}$ Myst. V, 3, 1-5; 4.

${ }^{46}$ Ibid. $\mathrm{V}, 11$

${ }^{47} \mathrm{Ibid}$. V, 16, 4. On fire as a purificatory medium see e.g. Eur. Hel. 869; Plut. de Is. et Os. 383d; Ov. Fast. 4, 727; Anth. Pal. 7, 49.

${ }^{48}$ Ibid. V, 16, 9-14.

${ }^{49}$ C. Gal. fr. 84, 21-25.

${ }^{50}$ Cf. C. Heracl. 213d-214a and the portrait of Diogenes C. Cyn. 199b.

${ }^{51}$ Cod. Theod. XVI, 10, 2 and 10, 4; 10, 6. For Julian's fondness in sacrifices see e.g. Amm. Marc. XXII, 5, 2. Cf. Lib. Or. XII, 69. On the topic, see further Belayche, 2001.

${ }^{52}$ Athanassiadi, 1981 is one of the most vivid example of such a tendency.

${ }^{53}$ Bradbury, 1995, 346.

${ }^{54}$ See e.g. ep. 88, 31; 450d; ep. 89a, 453a. On the role of pontifex maximus in the later empire see F. Van Haeperen, Le collège pontifical (3ème s.a. C. - 4ème s.p. C.), Brussels 2002, 161-186; R. Stepper, Augustus et sacerdos: Untersuchungen zum römischen Kaiser als Priester, Wiesbaden 2003, 207-209. On the understanding of such a role by Julian see A. Marcone, 'Giuliano e lo stile dell'imperatore tardoantico,' in: Rudiae 10 (1998) 43-58.

${ }^{55}$ N. Belayche, 'Realia versus Leges? Les sacrifices de la religion d'Etat au IVe siècle,' in Georgoudi-Koch Piettre-Schmidt, 2005, 343-370 (348). On dietary abstinentism as a widespread

Giorgio Scrofani, “"Like Green Herbs": Julian's Understanding of Purity and His Attitude Towards Judaism in His Contra Galilaeos,' in: Journal for Late Antique Religion and Culture 2 (2008) 1-16; ISSN: 1754-517X; Website: http://www.cardiff.ac.uk/clarc/jlarc.html 
the philosopher Maximus soon after Constantius'death Julian declares that now it

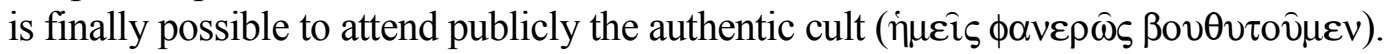
After mentioning the numerous hecatombs ( $\left.\dot{\varepsilon} \kappa \alpha \tau \tau^{\prime} \mu \beta \alpha \iota \pi \mathrm{o} \lambda \lambda \dot{\alpha}\right)$ of thanksgiving to the gods, Julian remembers the order received by the gods to purify everything as

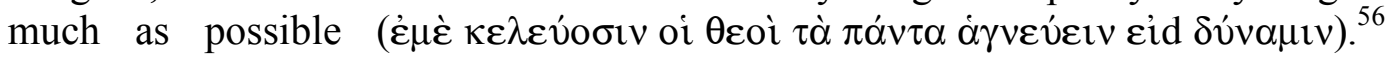
After the providential death of Constantius, the enemy of the gods, the sacrifices that Julian describes to Maximus have the function of thanksgiving. At the same time, as the nexus sacrifice/purifying suggests, they serve to expiate the evil of the Costantinides at the eve of a new beginning signalled by the dissipation of the clouds of atheism. ${ }^{57}$

Looking at the dietary laws we can observe much the same interest in Julian. Jewish dietary abstinence, especially from pork, was well known, and despised, by Greco-Roman intellectuals. But since the second and third centuries the fact that $\dot{\varepsilon} \gamma \kappa \rho \alpha ́ \tau \varepsilon ı \alpha$ was practised by neo-Pythagoreans and adherents of neo-orphic movements led to an increasingly positive evaluation of Jewish abstention too. ${ }^{58}$ Holy men from Pythagoras to Apollonius of Tyana were known and admired for their ascetic way of life. Meat consumption, for its ties to the material world and for its intrinsic qualities preventing the elevation of the soul, had to be avoided. This intellectual ecumenism culminated in the fourth book of Porphyry's 'On Abstinence'. In addition of the dietary habits of Egyptian priests and Brahmins Porphyry refers to the alimentary habits and the pure way ( $\left.\delta^{\prime} \alpha \imath \tau \alpha\right)$ of life obtained

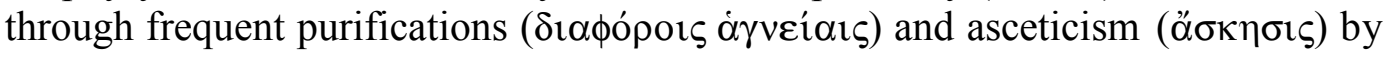
the Essenes described by Josephus as examples of the true, bloodless and priestly piety. ${ }^{59}$ But he also refers to the whole Law of Moses as a witness for the call to abstinence that imposes on the Jews a pure way of Life. ${ }^{60}$ Porphyry, as Josephus, saw in the Jewish practices a reflection of the Pythagorean doctrine. His admiration for the Essenes is linked to his argumentative target and philosophical theories. ${ }^{61}$ For other aspects of their religion the Jews are bitterly criticised in his 'Against Christians'.

Much more than Porpyry's 'On Abstinence', Julian's 'Against the Galileans' remains by far the most explicit reflection from this period on the interrelations

trans-cultural phenomenon in Late Antiquity see R.M. Grant, 'Dietary laws among Pythagoreans. Jews and Christians,' in: HTR 73 (1980) 299-310.

${ }^{56}$ Ep. 26, 415d.

${ }^{57}$ Misop. 362c.

${ }^{58}$ Already Plutarch in Quaest. Conv. 670d-1 viewed Jewish, Egyptian and Pythagorean dietary customs as different expressions of the same phenomenon. In particular, he uses Pythagorean abstinentism to justify the rationality of Jewish and Egyptian practices. See further Diog. Laert. 8, 13; Porph. Abst. I, 26; Iamblich. v. Pyth. 25 for a similar interpretation by Posidonius. Cf. Grant, 1980, 299-302. Such a syncretism was facilitated by the rational/allegorical interpretation of the Mosaic dietary laws in Jewish authors of the Hellenic diaspora such as Aristeas and Philo. On this point cf. G.M. Vian, 'Purità e culto nell'esegesi giudaico-ellenistica,' in: ASE 13 (1996) 67-84.

${ }^{59}$ Abst. IV , 5, 5. Porphyry follows here mainly the second book of Josephus' Bellum Iudaicum, in which the author treats the third Jewish 'philosophy', i. e. the one practised by the Essenes.

${ }^{60}$ Abst. IV, 14, 1-2.

${ }^{61}$ See e.g. Porph. v. Pyth. 7; 12; 43-45. On the relationship between Christian asceticism and Porphyry's argumentation see further G. Clark, 'Fattening the Soul: Christian asceticism and Porphyry on Abstinence,' in: Studia Patristica 35 (2001) 41-51.

Giorgio Scrofani, “"Like Green Herbs": Julian's Understanding of Purity and His Attitude Towards Judaism in His Contra Galilaeos,' in: Journal for Late Antique Religion and Culture 2 (2008) 1-16; ISSN: 1754-517X; Website: http://www.cardiff.ac.uk/clarc/jlarc.html 
and contrasting histories and values of the three religions together with Eusebius' Praeparatio and Demonstratio Evangelica and the later Augustine's De Civitate Dei. ${ }^{62}$ Nevertheless, Julian's evaluation of Jewish practices, just as Porphyry's, depends much on his observation of similarities with his own traditional heritage. In Julian's 'To the Mother of the Gods' sexual and alimentary abstinence is invoked as a means to achieve the purity required for the holy rites and the spiritual elevation of the worshipper. A large part of the work is consecrated to the purification rites preliminary to the Attis celebration. Julian shows that 'The end and the aim of the rite of purification is the ascent of our soul (A

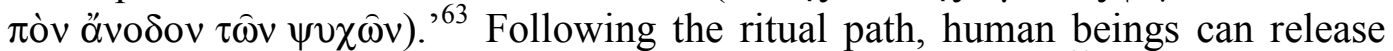
their soul, bound by corporal restraints, to the Great Mother. ${ }^{64}$ In the following paragraphs Julian lists all the different foods prohibited by the sacred law (ó icpò

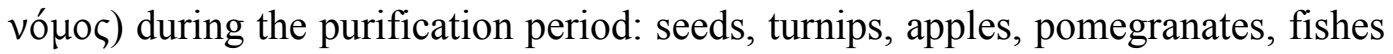
and pork. The unifying criterion, obviously artful, chosen by Julian to homologate all the different prescriptions, is their bond with the soil. If the aim of purification is the elevation of the souls, everything chthonian must be avoided as a consequence. Even if Graeco-Roman antiquity did not know a category of polluting animals, on certain occasions and in certain cults, not to mention the Pythagoreans, abstention was requested by sacred laws, ${ }^{65}$ even though they may in most cases have been temporary and oriented to the achievement of certain objectives. ${ }^{66}$

In conclusion to this section on the philosophical meaning of Jewish actual practices we can observe that both sacrifices and alimentary abstinences were seen by Julian as a subordinated, inferior, reflection of Hellenic worship. In this respect Jews were seen in a favourable light, because their cultic practices were clearly recognisable and visible. But they were not considered to possess absolute validity. They are mainly cited to support the argument. Neither Porphyry's nor Julian's approach is characterised by an in depth examination of Jewish doctrines, or the sincere search for an authentic similarity between Jewish and Greek traditions. References to Jews merely served Julian's aim to beat Christians on their home ground, namely the field of Scriptural interpretation, which they had already to defend against the Jews. At the same time they nourished inner divisions in the Church. As authors like Origen and John Chrysostom attest, the Jewish Day of Atonement continued to attract a great number of Christians, especially in SyroPalestinian communities such as Caesarea and Antioch, throughout the third and fourth centuries. ${ }^{67}$ This suggests a greater flexibility of the boundaries between

\footnotetext{
${ }^{62}$ Millar, 1992, 108.

${ }^{63}$ Ad Matr. Deor. $175 \mathrm{~b}$

${ }^{64}$ Ibid. $169 \mathrm{~b}$.

${ }^{65}$ See further R. Parker, Miasma: Pollution and Purification in early Greek Religion, Oxford 1983, 357-369.

${ }^{66}$ V. Grimm, From Feasting to Fasting, the Evolution of a Sin, London-New York 1996, 34-59.

${ }^{67}$ Cf. e.g. Orig. Hom. Jer. 12, 13-13. 17: Ioh. Crys. Adv. Jud. I, 1, 4. See further Stöckl Ben Ezra, 2003, 277-283. As put by L. Feldman, Jew and Gentile in the Ancient World. Attitudes and Interactions from Alexander to Justinian, Princeton 1993, 445: 'Judaism throughout the Hellenistic and Roman Periods and even after the triumph of Christianity showed tremendous vigor not only in strengthening itself internally with the development of that remarkable document, the Talmud, but also in reaching out to pagans and later to Christians and winning large numbers as proselytes

Giorgio Scrofani, “Like Green Herbs": Julian's Understanding of Purity and His Attitude Towards Judaism in His Contra Galilaeos,' in: Journal for Late Antique Religion and Culture 2 (2008) 1-16; ISSN: 1754-517X; Website: http://www.cardiff.ac.uk/clarc/jlarc.html
} 
Christianity and Judaism than is commonly assumed. Origen and John accused these 'Judaizing' Christians of having misunderstood, like the Jews, the 'real', i. e. spiritual meaning of the atonement ritual. Julian therefore entered a polemical discourse that already raged within the Christian community, when he denounced the illegitimacy of the christological (allegorical) interpretation of the narrative. While Gregory of Nyssa, Basil of Caesarea, John Crysostom, and many others claimed that purity laws were temporary and limited to Jews because of their inferiority, other Christians appealed to the normative authority of Leviticus and to its literal meaning. ${ }^{68}$ Julian's approach has to be properly understood in the light of this debate, of the inner divisions of the Church, especially at Antioch, and of the continuing attractiveness of Judaism for Christians. ${ }^{69}$

According to the evolutionist theory recently supported by Guy Stroumsa, the supposed extinction of blood sacrifice in the fourth century, albeit not as radical as Eusebius wanted it to be, would have subjected the concept of purity to a process of spiritualisation: 'Avec l'épuisement, l'interdiction, et finalement la quasi-extinction des rites sacrificiels, l'idée même de pureté rituelle, à l'évidence, sera mise à rude épreuve. Elle sortira de cette épreuve radicalement transformée, vers la fin de l'Antiquité. (...) L'eau des ablutions et du baptême remplaça pour les chrétiens et pour les Juifs le feu des sacrifices. Pour Porphyre l'âme est le temple intérieur et les rituels de pureté deviennent des règles d'ascèse. ${ }^{70}$ Following this view there should be an obvious conflict, but there is not. Even if the authentic purification

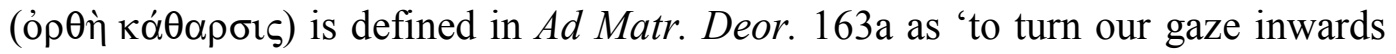

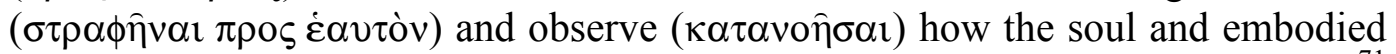
mind are a sort of mould and likeness of the form that are embodied in matter, ${ }^{71}$ Julian, like Iamblichus and even Porphyry, adds that 'by the rite of purification

and as "sympathizers" (...). Governments on the whole, finding them too numerous, too important economically, and generally loyal, were favourably disposed toward the Jews; and intellectuals, to a much greater degree than hitherto has been acknowledged, admired them.' Emblematic the Collatio legum Mosaicarum et Romanorum, a comparison between Jewish and Roman legislation, thought to have been redacted by a Jew in fourth century Rome. See further J.H.W.G. Liebeschuetz, 'The Influence of Judaism among Non-Jews in the Imperial Period,' in: JJS 52 (2001) 235-252; M. Goodman, 'The Jewish Image of God in Late Antiquity,' in R. Kalmin - S. Schwartz (ed.), Jewish Culture and Society under the Christian Roman Empire, Leuven 2003, 133-145; and F. Millar, 'Christian Emperors, Christian Church and the Jews of the Diaspora in the Greek East, CE 379450,' in: JJS 55 (2004) 1-24. A general overview on the relationship between Jews and Roman empire in S. Schwartz, Imperialism and Jewish Society, 200 B.C.E.to 640 C.E., Princeton 2001.

${ }^{68}$ For evidence see C.E. Fornrobert, 'The Didascalia Apostolurm: A Mishnah for the Disciples of Jesus,' in: JECS 9 (2001) 483-509; A. Letho, 'Moral, Ascetic, and Ritual Dimensions to LawObservance in Aphrahat's Demonstrations,' in: JECS 14 (2006) 157-181. On Judaeo-Christian sects who followed, at least partially, Jewish purity laws see Epiph. Panar. 28, 5, 1; Greg. Naz. Or. XVIII, 5; Basil. epp. 188, 1; 265, 2. Further D. Brakke, 'The Problematization of Nocturnal Emissions in Early Christian Syria, Egypt, and Gaul,' in: JECS 3 (1995) 419-460 for nocturnal emissions as cause of pollution in the fourth century Egypt, Syria and Gaul.

${ }^{69}$ For Antioch see J. Hahn, Gewalt und religiöser Konflikt. Studien zu den Auseinandersetzungen zwischen Christen, Heiden und Juden im Osten des Römischen Reiches (von Konstantin bis Theodosius II), Berlin 2004, 157-159.

${ }^{70}$ Stroumsa, 2005, 147.

${ }^{71}$ As in ep. 82, 445a. Cf. further Procl. In. Tim. III, 296,7-297, 1.

Giorgio Scrofani, “"Like Green Herbs": Julian's Understanding of Purity and His Attitude Towards Judaism in His Contra Galilaeos,' in: Journal for Late Antique Religion and Culture 2 (2008) 1-16; ISSN: 1754-517X; Website: http://www.cardiff.ac.uk/clarc/jlarc.html 
( $\delta i \grave{\alpha} \tau \hat{\eta} \varsigma \dot{\alpha} \gamma 1 \sigma \tau \varepsilon i \alpha \varsigma)$ not the soul alone but the body as well is greatly benefited

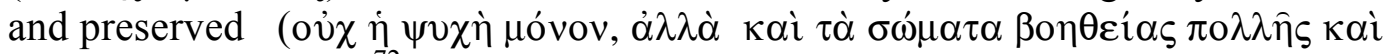
$\sigma \omega \tau \eta \rho i \alpha \varsigma \alpha \dot{\alpha} \xi 10 \hat{\tau} \alpha \imath) .{ }^{, 72}$ The authenticity and reliability of such practices, thus Julian, are granted by the godly exhortations of the most holy among the theurgists'

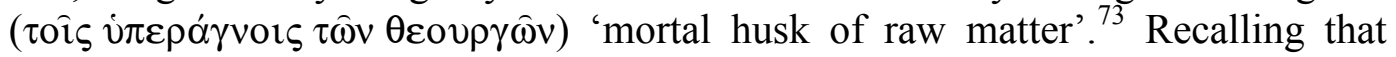
according to Julian, Judaism derived its practices from Chaldea, the reason why Jews and Hellenes are similar becomes self-evident. In contrast to Stroumsa's view Julian uses the Jewish idea of purity in support of his own idea of purity, which he develops in fundamental opposition to the Christian idea; and this is consistent with Julian's view that Christianity is a complete abomination. For Julian it is the Christians who - wrongly! - hold a spiritualised concept of purity. In New Testamentary Greek the term órvei $\alpha$ indicates the purity condition achieved by the believer not through a ritual act but by a way of conduct inspired by the ex-ample of Jesus. ${ }^{74}$ Consequently, among the Church fathers $\dot{\alpha} \gamma v \varepsilon i \alpha$ is the obedience to the Gospel and especially asceticism and chastity. ${ }^{75}$ The fathers mention ritual óyveía only in reference to Jews and pagans. Julian's understanding is diametri-cally opposed to this. For him the standards are set by what he perceives to be the Jewish practice. As for Porphyry, purity for Julian is never entirely spiritual but it still remains the most important cultic precondition. In 'Against the Galileans' Ju-lian (as reported by Gregory of Nazianzus and Sozomenos) expresses revulsion at the Christian concept of katharsis, as realised in particular in the ritual of baptism. In Julian's view the latter constitutes a hopelessly inadequate means of salvation. As already mentioned, in the letter to the inhabitants of Bostra Julian requested an elaborate ritual purification of converted Christians. ${ }^{76}$ Also 'Against the Galileans' Julian criticised Christian burial practices and in particular the cult of the Martyrs, because they constitute a concrete cause of pollution. ${ }^{77}$ This should not be taken as a reflection of Pythagorean abhorrence of death. Julian ordered the removal of the earthly remains of St. Babylas from the neighbourhood of the Castalian spring at Daphne and the ritual purification of the place ${ }^{78}$ and the corpses buried near the temple of Dydima, ${ }^{79}$ praised the citizens of Emesa for burning Christian churches, which in

\footnotetext{
${ }^{72}$ Even if philosophy is the highest form of purification (see e.g. ep. 82, 445a), Neoplatonism saw purification as a process involving both mind and body. See R. van den Berg, 'Becoming like God according to Proclus' interpetations of the Timaeus, the Eleusinian Mysteries, and the Chaldean Oracles,' in R. W. Sharples - A. Sheppard (ed.), Ancient Approaches to Plato's Timaeus, London 2003, for Proclus' portrait in Marinus' Life. Cf. e.g. Mar. v. Procl. 18, 27-34.

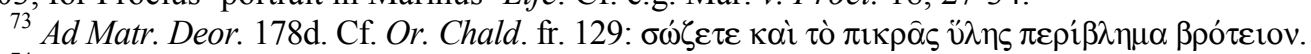

${ }^{74}$ See e.g. Jn 3, 3; Jas 4, 8-9; 1Pet 1, 22.

${ }^{75}$ As in Cypr. de habi. III, 11-18; XVII ; Basil. Reg. Brev. 67 ; 309; Bapt. 2,2; Athan. v. Ant. 7; 14, 4. See P. Brown, The Body and Society, London 1988, 178-83; M. Girardi, 'Puro/impuro in Basilio di Cesarea: da categoria cultuale a discrimine paolino di fraternità,' in: ASE 13 (1996) 159177; J.G.D. Dunn, 'Infected Sheep and diseased Cattle, or the pure and holy Flock: Cyprian's pastoral Care of Virgins,' in: JECS 11 (2003) 1-20.

${ }^{76}$ See above note 25 .

${ }^{77}$ C. Gal. fr. 81.

${ }^{78}$ Amm. Marc. XXII, 18, 8.

${ }^{79}$ Soz. V, 20, 7.
}

Giorgio Scrofani, "Like Green Herbs": Julian's Understanding of Purity and His Attitude Towards Judaism in His Contra Galilaeos,' in: Journal for Late Antique Religion and Culture 2 (2008) 1-16; ISSN: 1754-517X; Website: http://www.cardiff.ac.uk/clarc/jlarc.html 
his view had been defiled by having been used as tombs, ${ }^{80}$ and declared all daytime funerals illegal. ${ }^{81}$ Writing to Theodorus at the beginning of 363 he requested of pagan priests not only spiritual, but also physical purity. ${ }^{82}$ Scholars generally attribute this preoccupation with purifications to the intended archaism of Julian, and they explain his obsession for ritual purity as deriving from the strict Neoplatonic doctrine of Iamblichus. ${ }^{83}$ But Julian's main concern was not to meet the require-ments of a particular Neoplatonic sect, but to preserve the empire and its purity, the pax deorum undermined by Christian atheism and fanaticism. A similar concern can be detected in Maximinus Daia's anti-Christian policy at the beginning of the fourth century. ${ }^{84}$

Julian's rituals of purification are in line with the old imperial tradition and with the analogous Roman and Greek rituals: they define group boundaries, separating 'us' from 'he others' and protecting the core of Roman/Hellenic tradition from danger coming from outsiders. Contrary to the leading opinion, defilement and purity in Late Antiquity cannot be considered only as synonymous of a spiritual condition: the cultic meaning of purification is never entirely physical or spiritual, even in highly spiritualised religions such as Christianity or Islam.

\section{Conclusion: The Polemical Role of Judaism in 'Against the Galileans'}

Analysing the Yom Kippur ritual and the dietary laws of Leviticus Julian in 'Against the Galilaeans' argues that Christians are not only impious and blasphemous but also impure from a strictly cultic perspective. Indeed they abandoned Jewish purification customs claiming that the new Law of Christ surpassed the old Law of Moses. But in invoking the Law of Moses Julian's aim is not to demonstrate tout court the superiority of Judaism, but to destroy the Christian pretence to be the true Israel.

Until now it has not been sufficiently appreciated that Judaism was in fact of little use for Julian to prove the intrinsic validity of Hellenic worship. At the end of the

\footnotetext{
${ }^{80}$ Misop. 357c.

${ }^{81}$ Cod. Theod. IX, 17, 5 (February 363).

${ }^{82}$ Ep. 89b, 293a, 1-3.

${ }^{83}$ Representatives of this trend are Bowersock, 1978, 93; P. Chuvin, Chronique des derniers païens: la disparition du paganisme dans l'Empire romain, du règne de Constantin à celui de Justinien, Paris 1991, 242-243; E. Soler, 'D'Apollonios de Tyane à l'empereur Julien: l'importance d'Antioche comme lieu de pèlerinage et centre philosophique grecs,' in B. Cabouret - P. Gatier - C. Saliou (ed.), Antioche de Syrie: histoire, images et traces de la ville antique. Colloque tenu à Lyon, Maison de l'Orient méditerranéen, 4-6 octobre 2001, Lyon 2004, 381-399; Stroumsa, 2005, 88. For a more critical approach cf. W. Koch, 'Comment l'empereur Julien tâcha de fonder une église païenne,' in: RBPh 7 (1928) 543-554 (543-547); J. Malley, Hellenism and Christianity: The Conflict between Hellenic and Christian Wisdom in the Contra Galilaeos of Julian the Apostate and the Contra Iulianum of St. Cyril of Alexandria, Rome 1978, 128-144; O. Nicholson, 'The Pagan Churches of Maximinus Daia and Julian the Apostate,' in: JEH 45 (1994). But even these fall short of providing general interpretative frameworks for the relevant concepts and rituals of purification.

${ }^{84}$ See R.M. Grant, 'The Religion of Maximin Daia,' in J. Neusner, Christianity, Judaism and other Greco-Roman Cults. Studies for Morton Smith at sixty, Leiden 1975, IV, 143-166; S. Mitchell, 'Maximinus and the Christians in A.D. 312. A new Latin inscription,' in: JRS 88 (1988) 105-124; Nicholson, 1994.
} 
day Jews were no credible allies for Julian in his task of recovering Hellenism from the iron dark age of the Constantinian period. They had never had, nor would they ever have, a share in the empire. They are mentioned and praised only in polemical contexts, in contrast to the Christians. Their doctrines are never discussed outside the 'Against the Galileans' and in some letters from the same period, in contrast, for example, to the doctrines of the Egyptians, which are exploited to demonstrate the antiquity of Helios worship in the 'Hymn to King Helios'. 85

Moreover, although Julian did note other features of contemporary Judaism, e. g. mutual Jewish charity, the kind of Judaism which attracted him most no longer existed. It had vanished with the temple. Julian's main aim in 'Against the Galileans' was to refute Christianity. His support of Judaism in the course of this refutation was a by-product. Only when we consider the continuing attraction which Judaism held for Christians, especially in Antioch, we can properly understand Julian's polemics. Favouring the Jews and supporting the literal interpretation of Scripture on the one hand he affirmed indirectly the Hellenic pure way of life, on the other hand he tried to nourish inner-Christian conflicts.

${ }^{85}$ Ad Hel. Reg. 155b.

Giorgio Scrofani, “Like Green Herbs": Julian's Understanding of Purity and His Attitude 